University of Nebraska - Lincoln

DigitalCommons@University of Nebraska - Lincoln

Faculty Publications from the Harold W. Manter Laboratory of Parasitology

April 2010

\title{
Species of Coccidia (Apicomplexa: Eimeriidae) Infecting Pikas from Alaska, U.S.A. and Northeastern Siberia, Russia
}

\author{
A. J. Lynch \\ University of New Mexico \\ Donald W. Duszynski \\ University of New Mexico, eimeria@unm.edu \\ Joseph A. Cook \\ University of New Mexico
}

Follow this and additional works at: https://digitalcommons.unl.edu/parasitologyfacpubs

Part of the Parasitology Commons

Lynch, A. J.; Duszynski, Donald W.; and Cook, Joseph A., "Species of Coccidia (Apicomplexa: Eimeriidae) Infecting Pikas from Alaska, U.S.A. and Northeastern Siberia, Russia" (2010). Faculty Publications from the Harold W. Manter Laboratory of Parasitology. 139.

https://digitalcommons.unl.edu/parasitologyfacpubs/139

This Article is brought to you for free and open access by the Parasitology, Harold W. Manter Laboratory of at DigitalCommons@University of Nebraska - Lincoln. It has been accepted for inclusion in Faculty Publications from the Harold W. Manter Laboratory of Parasitology by an authorized administrator of DigitalCommons@University of Nebraska - Lincoln. 


\title{
RESEARCH NOTES
}

J. Parasitol., 93(5), 2007, pp. 1214-1216

(C) American Society of Parasitologists 2007

\section{Seroprevalence of Toxoplasma gondii Antibodies in Cats From Durango City, Mexico}

\author{
C. Alvarado-Esquivel, O. Liesenfeld ${ }^{\star}$, R. G. Herrera-Flores $\dagger$, B. E. Ramírez-Sánchez†, A. González-Herrerał, S. A. Martínez-García, and \\ J. P. Dubey§, Facultad de Medicina, Universidad Juárez del Estado de Durango, Dgo Mexico, Avenida Universidad y Fanny Anitua, 34000 \\ Durango, Dgo. Mexico; *Institute for Microbiology and Hygiene, Campus Benjamin Franklin, Charité Medical School Berlin, Hindenburgdamm \\ 27, D-12203 Berlin, Germany; †Animal Shelter Municipal Office of Public Health and Environment, Durango, Mexico, Carretera a Mexico S/N, \\ Durango, Dgo. Mexico; ¥Secretary of Health, Durango, Mexico. Cuauhtemoc 225 norte, 34000 Durango, Dgo. Mexico; §To whom \\ correspondence should be addressed. United States Department of Agriculture, Agricultural Research Service, Animal and Natural Resources \\ Institute, Animal Parasitic Diseases Laboratory, Building 1001, Beltsville, Maryland 20705-2350. e-mail: jitender.dubey@anri.usda.gov
}

ABSTRACT: The prevalence of antibodies to Toxoplasma gondii was determined in sera from 105 domestic cats from Durango City, Mexico. Using a modified agglutination test, antibodies to this parasite were found in $21 \%$ of the 105 cats, with titers of $1: 25$ in 3 cats, $1: 50$ in 4 cats, $1: 200$ in 5 cats, $1: 400$ in 2 cats, $1: 800$ in 2 cats, 1:1,600 in 4 cats, and $1: 3,200$ or higher in 2 cats. Cats older than $1 \mathrm{yr}$ had a significantly higher frequency of infection than that found in cats younger than 0.5 $\mathrm{yr}$ (41 vs. $13.2 \%$, respectively; odds ratio $=4.55 ; 95 \% \mathrm{CI}=1.24$ 17.18; $P=0.01$ ). Overall, the seroprevalence of $T$. gondii antibodies in cats in Durango, Mexico, is much lower compared with those reported in other countries.

Cats are essential in the life cycle of Toxoplasma gondii because they are the only hosts that can excrete the environmentally resistant oocysts in nature (Dubey and Beattie, 1988). Little is known of the prevalence of $T$. gondii in cats in Mexico. In the present report, we determined the prevalence of $T$. gondii infection in cats from Durango City, Mexico, and we attempted to identify general characteristics of cats associated with infection.

All 105 unwanted cats enrolled from August to November 2006 in the animal shelter in Durango City, Mexico, were studied. The animal shelter receives stray cats captured by the municipality from the streets of Durango City and unwanted pet cats given by the owners for adoption. General data, including age, breed, gender, health status, origin (stray or household), type of food eaten, and residence for cats were obtained (Table I).

The sera were transported by courier from Mexico to Beltsville, Maryland, where serology was performed. Two-fold serial dilutions were made $(1: 25-1: 3,200)$ and tested with a modified agglutination test (MAT), as described previously (Dubey and Desmonts, 1987). Whole formalin-fixed tachyzoites and mercaptoethanol were used as antigen, and a titer of 1:20 or higher was considered indicative of $T$. gondii exposure based on experimental studies in cats (Dubey and Thulliez, 1989; Dubey et al., 1995a, 1995b).

Results were analyzed with the aid of the software Epi Info 6. For comparison of the frequencies among the groups, the Mantel-Haenszel test, and when indicated the Fisher exact test, were used. The association of the animal characteristics and the $T$. gondii infection was assessed by calculating the odds ratio (OR) with a $95 \%$ confidence interval (CI). For age comparison among groups of cats the Student's $t$-test was used. A $P$ value of less than 0.05 was considered significant.

Antibodies to T. gondii were found in $21 \%$ of the 105 cats, with titers of $1: 25$ in 3 cats, $1: 50$ in 4 cats, $1: 200$ in 5 cats, 1:400 in 2 cats, 1:800 in 2 cats, 1:1,600 in 4 cats, and 1:3,200 or higher in 2 cats.

General characteristics of 105 cats are shown in Table I. All cats were of crossbreed and resided in urban areas. Most cats studied were females, and the frequency of $T$. gondii infection observed in these females was similar to that observed in male cats $(P=0.56)$. Cats were 1 mo to $7 \mathrm{yr}$ old (mean $9 \mathrm{mo}$ ), and the prevalence of infection increased with age. Most cats were healthy, and the prevalence of infection in this group did not differ from that in ill cats $(P=0.33)$. In addition, most cats studied were pets. The prevalence of infection in male and female cats in the stray group was comparable $(33.3$ and $31.3 \%$, respectively; $P=0.61$ ). Similarly, although the prevalence of infection in pet female cats $(20 \%)$ was 2 -fold higher than that observed in pet male cats $(9.1 \%)$, the overall prevalence of infection in male and female cats did not differ significantly $(P=0.21)$.

Cats older than $1 \mathrm{yr}$ had a significantly higher frequency of infection than cats younger than $0.5 \mathrm{yr}$ ( 41 vs. $13.2 \%$, respectively; $\mathrm{OR}=4.55$; $95 \% \mathrm{CI}=1.24-17.18 ; P=0.01)$ and slightly higher than that observed in cats 0.5 to $1 \mathrm{yr}$ old ( 41 vs. $20 \% ; P=0.18$ ). Toxoplasma gondii seroprevalence in stray cats is much higher in stray versus pet cats (Dubey, 1973; DeFeo et al., 2002; Nutter et al., 2004) as was the case in the present study. Higher seroprevalence in adult cats versus kittens, observed in the present study, supports earlier findings (Dubey, 1973; Ruiz and Frenkel, 1980b; Pena et al., 2006) and relates to the life cycle of $T$. gondii in cats; most cats are thought to become infected with $T$. gondii after weaning when they begin to hunt for food.

The $21 \%$ prevalence of $T$. gondii antibodies in cats of Durango City, Mexico, in the present study is the lowest among all other surveys from North and South America, West Indies, and 1 study from Europe using a cut-off MAT titer of 1:20 (Table II). The prevalence of $T$. gondii in cats is a reflection of prevalence of $T$. gondii in animals that cats access for food. For example, Ruiz and Frenkel (1980a, 1980b) found a very high prevalence of $T$. gondii in cats and rodents and free-range chickens from Costa Rica. Although there are several reports of $T$. gondii infection in humans and animals in Mexico (Varela et al., 1961; FernandezTorrano et al., 1986; Velasco-Castrejon et al., 1992; Galvan Ramirez et al., 1995, 1997; Del Rio-Chiriboga et al., 1997; Dubey, Morales, and

TABLE I. General characteristics of the cats and prevalence of $T$. gondii antibodies.

\begin{tabular}{|c|c|c|c|c|}
\hline \multirow[b]{2}{*}{ Characteristic } & \multicolumn{2}{|c|}{ Cats studied } & \multicolumn{2}{|c|}{ Cats positive } \\
\hline & No. & $\%$ & No. & $\%$ \\
\hline \multicolumn{5}{|l|}{ Gender } \\
\hline Male & 34 & 32.4 & 6 & 17.6 \\
\hline Female & 71 & 67.6 & 16 & 22.5 \\
\hline \multicolumn{5}{|l|}{ Age groups (yr) } \\
\hline$<0.5$ & 53 & 50.4 & 7 & 13.2 \\
\hline $0.5-1$ & 30 & 28.6 & 6 & 20 \\
\hline$>1$ & 22 & 21 & 9 & 41 \\
\hline \multicolumn{5}{|l|}{ Residence area } \\
\hline Urban & 105 & 100 & 22 & 21 \\
\hline \multicolumn{5}{|l|}{ Health status } \\
\hline Healthy & 95 & 90.5 & 21 & 22.1 \\
\hline Ill & 10 & 9.5 & 1 & 10 \\
\hline \multicolumn{5}{|l|}{ Origin } \\
\hline Stray & 28 & 25.7 & 9 & 32.1 \\
\hline Household & 77 & 73.3 & 13 & 16.9 \\
\hline \multicolumn{5}{|l|}{ Breed } \\
\hline Crossbreed & 105 & 100 & 22 & 21 \\
\hline \multicolumn{5}{|l|}{ Food } \\
\hline Commercial & 91 & 86.7 & 19 & 20.9 \\
\hline Homemade & 66 & 62.9 & 13 & 19.7 \\
\hline Hunting and garbage & 30 & 28.6 & 9 & 30 \\
\hline
\end{tabular}


snails (Physa sp.) continued throughout the winter. MacKenzie et al. (1995) cited an abstract of Hoglund and Thulin who reported no change in parasitism.

In summary, exposure of a cold-water, benthic, sedentary flatfish to thermal effluent discharged $5 \mathrm{~m}$ above the plume apparently caused no effect on body condition, organ indices, or hematological or pathological alterations. However, prevalence, or mean abundance, or both of some parasites of the fish were affected below the plume, 1 species increasing and 6 species declining. This observation suggests either sensitivity to the effluent or interruption of transmission via their intermediate hosts near the thermal plume. These results provide additiona evidence to support the view that some parasites of fish can be useful as bioindicators of subtle environmental changes.

We are grateful to M. O'Keefe for technical assistance and to S. Wall for typing the manuscript. The study was supported by a contract and the Natural Sciences and Engineering Council of Canada.

\section{LITERATURE CITED}

ADAms, S. M. 1990. Status and use of biological indicators for evaluating the effects of stress on fish. In Biological indicators of stress in fish, S. M. Adams (ed.). American Fisheries Society Symposium 8: $1-8$.

Aho, J. M., J. W. CAMP, AND G. W. Esch. 1982. Long-term studies on the population biology of Diplostomulun scheuringi in a thermally altered reservoir. Journal of Parasitology 68: 695-708.

Arthur, J. R., D. K. Cone, R. L. Cusack, D. E. Barker, and M. D B. BuRT. 2004. Two species of Trichodina (Ciliophora: Peritrichida) from cultured flatfishes (Pleuronectiformes) in Atlantic Canada. Comparative Parasitology 71: 247-250.

BArker, D. E., D. K. CONE, AND M. D. B. BurT. 2002. Trichodina murmanica (Ciliophora) and Gyrodactylus pleuronecti parasitising hatchery-reared winter flounder, Pseudopleuronectes americanus (Walbaum): Effects on host growth and assessment of parasite interaction. Journal of Fish Diseases 25: 81-89.

BoXruCKER, J. C. 1979. Effects of a thermal effluent on the incidence and abundance of the gill and intestinal parasites of the black bullhead. Parasitology 78: 195-206.

CAmp, J. W., J. M. AHo, AND G. W. Esch. 1982. A long-term study on various aspects of the population biology of Ornithodiplostomum ptychocheilus in a South Carolina cooling reservoir. Journal of Parasitology 68: 709-718.

Esch, G. W., T. C. Hazen, R. V. Dimock, and J. W. Gibbons. 1976 Thermal effluent and the epizootiology of the ciliate Epistylis and the bacterium Aeromonas in association with centrarchid fish. Transactions of the American Microscopical Society 95: 687-693.

Eure, H. E., AND G. W. EsCH. 1974. Effects of thermal effluent on the population dynamics of helminth parasites in large mouth bass. In Thermal ecology, J. W. Gibbons and R. R. Sharitz (eds.). AEC Symposium Series (CONF-730505), Oak Ridge Tennessee Technical Information Center, U.S. Atomic Energy Commission, Oak Ridge, Tennessee, p. 237-243.
George-Nascimento, M., R. A. Khan, F. Garcias, V. Lobos, G MuÑoz, AND V. VAldebenito. 2000. Impaired health in flounder, Paralichthus spp. inhabiting coastal Chile. Bulletin of Environmental Contamination and Toxicology 64: 84-190.

Hirshfield, M. F., R. P. Morin, And D. J. HePner. 1983. Increased prevalence of larvae Eustrongylides (Nematoda) in the mummicheg, Fundulus heteroclitus (L.) from a discharge canal of a powerplant in the Chesapeake Bay. Journal of Fish Biology 23: 135142.

KHAN, R. A. 2003. Stress-related bioindicator anomalies in feral male winter flounder (Pleuronectes americanus) exposed to effluent from two pulp and paper mills in Newfoundland. Bulletin of Environmental Contamination and Toxicology 70: 401-407.

- 2004. Parasites of fish as biomarkers of environmental degradation: A field study. Bulletin of Environmental Contamination and Toxicology 72: 394-400.

- AND K. NAG. 1993. Estimation of hemosiderosis in seabirds and fish exposed to petroleum. Bulletin of Environmental Contamination and Toxicology 50: 125-131.

- AND J. THULIN. 1991. Influence of pollution on parasites of aquatic animals. Advances in Parasitology 30: 201-238.

LAFFERTY, K. D. 1997. Environmental parasitology: What can parasites tell us about human impacts on the environment. Parasitology Today 13: 251-255.

Landicci, C., F. Rossi, and F. Maltagliati. 1999. Detection of thermal pollution: Variability of benthic communities at two different spatial scales in an area influenced by a coastal power station. Marine Pollution Bulletin 38: 296-303.

LGL LTD. 1999. Characterisation of the thermal plume at the Holyrood Thermal Generating Station, Seal Cove, Newfoundland, during February 1998 to March 1999, SA575, LGL publication, St. John's, NF, Canada, 29 p.

MacKenzie, K., H. H. Williams, B. Williams, A. H. McVicar, and R. SidDALL. 1995. Parasites as indicators of water quality and the potential use of helminth transmission in marine pollution studies. Advances in Parasitology 35: 86-144.

PojMANSKA, T., AND E. DZIKA. 1987. Parasites of bream (Abramis brama L.) from the lake Goslawskie (Poland) affected by long-term thermal pollution. Parasitologica Polonca 32: 139-161.

Sankurathri, C. S., AND J. C. Holmes. 1976. Effects of thermal effluents on parasites and commensals of Physa gyrini Say (Mollusca; Gastropoda) and their interactions at Lake Wabamun, Alberta. Canadian Journal of Zoology 54: 1742-1753.

SeKhar, S. E., AND W. Threlfall. 1970. Helminth parasites of cunner, Tautogolabrus adspersus (Walbaum) in Newfoundland. Journal of Helminthology 44: 169-188.

Suresh, K., M. S. Ahamed, G. Durairaj, and K. V. K. Nair. 1993. Impact of a power plant heated effluent on the abundance of sedimentary organism, off Kalpakkan, east coast of India. Hydrobiologia 268: 109-114.

\section{Species of Coccidia (Apicomplexa: Eimeriidae) Infecting Pikas From Alaska, U.S.A. and Northeastern Siberia, Russia}

A. J. Lynch, D. W. Duszynski, and J. A. Cook, Department of Biology, The University of New Mexico, Albuquerque, New Mexico 87131 e-mail: eimeria@unm.edu

ABSTRACT: Eighty-eight fecal samples from 2 species of pika, Ochotona collaris and Ochotona hyperborea, collected in Alaska $(\mathrm{N}=53)$ and Russia $(\mathrm{N}=35)$, respectively, were examined for the presence of coccidia (Apicomplexa: Eimeriidae). Five oocyst morphotypes were observed. In $O$. collaris, we found Eimeria calentinei, Eimeria crypto- barretti, and Eimeria klondikensis, whereas in O. hyperborea, we found Eimeria banffensis, E. calentinei, E. cryptobarretti, E. klondikensis, and Isospora marquardti. This study represents new geographic records for all 5 coccidia and new host records for E. cryptobarretti and I. marquardti. Only minor quantitative differences were seen between the 
sporulated oocysts we studied and those reported in their original descriptions.

Pikas are holarctic lagomorphs composed of the single genus, Ochotona, with 30 species (Wilson and Reeder, 2005). The majority of species are found in Asia, mainly in the Tibet (Qinghai-Xizang) Plateau region, but also in Afghanistan, Burma, China, India, Iran, Japan, Kazakhstan, Korea, Nepal, Pakistan, and Russia, whereas only 2 species are found in North America (Chapman and Flux, 1990; Yu et al., 2000; Wilson and Reeder, 2005). Currently, 18 coccidia species (16 Eimeria, 2 Isospora) are described from all Ochotona species. Over 3 summer field seasons (2000-2002), the collared pika, Ochotona collaris (Nelson, 1893), and the northern pika, Ochotona hyperborea (Pallas, 1811), were collected in Alaska and northeastern Siberia, Russia, respectively, as part of the Beringia Coevolution Project (Hoberg et al., 2003; Cook et al., 2005). The present study was conducted to assess the similarity of coccidia fauna in 2 closely related hosts geographically separated by the Bering Strait.

Pikas were caught with museum snap traps or shot with firearms. Fecal specimens were taken from 88 animals from 6 regional field sites: $O$. collaris were collected from 2 sites in Alaska $(\mathrm{N}=53)$, whereas $O$. hyperborea were collected from 4 sites in northeastern Siberia, Russia $(\mathrm{N}=35)$. The Alaskan sites were Wrangell-St. Elias National Park and Yukon-Charley Rivers National Preserve; 4 regions in northeastern Siberia were sampled, the Omolon, Anadyr, and Kolyma river basins and the Providenya Oblast. Symbiotype host specimens (Frey et al., 1992; Brooks, 1993), in which all oocyst species/forms were seen and identified here, are maintained in the University of Alaska Museum of the North (UAM). Feces were preserved in $2.5 \%$ (w/v) aqueous $\mathrm{K}_{2} \mathrm{Cr}_{2} \mathrm{O}_{7}$ solution. Oocysts were isolated, measured, and photographed as described by Duszynski and Wilber (1997).

In all, $25 \%(22 / 88)$ of the samples were positive: $12 / 35$ (34\%) $O$. hyperborea, and 10/53 (19\%) O. collaris. Only 4 pikas were host to multispecies infections of coccidia. Five distinct oocyst morphotypes were observed and these were consistent with previously recognized coccidia species from other pikas. Three coccidia species were recovered from O. collaris: Eimeria calentinei, Eimeria cryptobarretti, and Eimeria klondikensis; 5 were recovered from O. hyperborea: Eimeria banffensis, E. calentinei, E. cryptobarretti, E. klondikensis, and Isospora marquardti. The recovery of E. cryptobarretti from $O$. collaris and $O$. hyperborea represents 2 new host records. Previously, E. cryptobarretti only had been found in Ochotona princeps, the American pika, in Colorado (Duszynski and Brunson, 1973). The recovery of I. marquardti from $O$. hyperborea also represents a new host record. The recovery of 3 species of coccidia in Alaskan $O$. collaris represents geographic range extensions, as does the recovery of 5 species from $O$. hyperborea in Siberia. Both hosts were studied by Hobbs and Samuel (1974) from pikas collected in the Yukon Territory, Canada, (O. collaris) and Japan (O. hyperborea); in 92 O. collaris they reported E. banffensis, Eimeria barretti, Eimeria circumborealis, Eimeria princeps, I. marquardti, and Isospora yukonensis, and in 14 O. hyperborea they recovered E. circumborealis, E. princepsis, and Eimeria worleyi.

Because there have been so few published reports of coccidia from these hosts, we include brief mention of qualitative or quantitative (or both) structures as they differ from the original descriptions, along with taxonomic summaries of the species recovered.

\section{Eimeria banffensis Lepp, Todd, and Samuel, 1973}

Type host: O. princeps (Richardson, 1828), American pika.

Other hosts (this study): O. hyperborea.

Type locality: North America: Canada: Alberta, Banff, Jumpingpound, and Sibbald creeks.

Geographic distribution: North America: Canada: Alberta, Banff, Jumpingpound, and Sibbald creeks, $51^{\circ} \mathrm{N}, 115^{\circ} \mathrm{W}$; Yukon Territory, Ogilvie Mountains, $64^{\circ} \mathrm{N}, 138^{\circ} \mathrm{W}$; U.S.A.: Colorado, Larimer and Clear Creek counties; Asia: Japan: Hokkaido, Daisetzusan National Park; Russia: Siberia, Chukotka, $3 \mathrm{~km}$ SSE of confluence of Volchya River and Liman Sea, $64^{\circ} 48^{\prime} \mathrm{N}, 177^{\circ} 33^{\prime} \mathrm{E}$ (this study).

Prevalence: $5 / 92(5 \%)$ O. collaris (type host) in Yukon Territory; 3/14 (21\%) O. hyperborea in Japan; 5/35 (14\%) O. hyperborea in Russia (this study); 40/167 (24\%) O. princeps in Colorado; 11/145 (8\%) O. princeps in Alberta.
Material deposited: Skull, skeleton, and tissues of a symbiotype host (this study) are preserved in UAM, as UAM no. 84368 (IF 5252), male, 11 August 2002 (collected by N. E. Dokuchaev, A. A. Tsvetkova). Photosyntype of sporulated oocysts are in the U.S. National Parasite Collection (USNPC) as USNPC no. 87390.

Remarks: The morphology of E. banffensis from $O$. hyperborea in Russia is similar to the original description provided by Lepp et al. (1973) for this species collected and described from $O$. princeps in Alberta, Canada. Whereas Duszynski and Brunson (1973) described oocysts that were nearly $2 \mu \mathrm{m}$ smaller in both length and width, the oocyst sizes of our Russian oocysts did not differ when compared with the original specimens $(30 \times 25$ vs. $30 \times 25)$. Duszynski and Brunson (1973) and Hobbs and Samuel (1974) failed to detect the $\sim 2-\mu \mathrm{m}$ polar granule that was observed in both this study and the original study by Lepp et al. (1973). The recovery of E. banffensis is a new geographic record for this parasite in Russia.

\section{Eimeria calentinei Duszynski and Brunson, 1973}

Type host: O. princeps (Richardson, 1828), American pika. Other hosts (this study): O. collaris, O. hyperborea.

Type locality: North America: Colorado, Larimer County.

Geographic distribution: North America: Canada: Yukon Territory, Ogilvie Mountains, $64^{\circ} \mathrm{N}, 138^{\circ} \mathrm{W}$, Alberta, $51^{\circ} \mathrm{N}, 115^{\circ} \mathrm{W}$; U.S.A.: Colorado: Clear Creek and Larimer counties; Alaska: Yukon-Charley Rivers National Preserve, NW of Rocky Slope of Mt. Kathryn, S of Woodchopper Creek, $65^{\circ} 12^{\prime} \mathrm{N}, 143^{\circ} 33^{\prime} \mathrm{W}$ (this study); Asia: Japan: Hokkaido, Daisetzusan National Park; Russia: Siberia, Magadanskaya Oblast, 40 $\mathrm{km}$ W Magadan, $59^{\circ} 41^{\prime} \mathrm{N}, 150^{\circ} 20^{\prime} \mathrm{E}$ (this study).

Prevalence: 5/53 (9\%) O. collaris in Alaska (this study); 8/92 (9\%) $O$. collaris in Yukon Territory; 2/35 (6\%) O. hyperborea in Siberia (this study); 1/14 (7\%) O. hyperborea in Japan; 2/111 (2\%) O. princeps in Alberta; 39/167 (23\%) O. princeps (type host) in Colorado.

Material deposited: Skin, skull, skeleton, and tissues of 2 symbiotype hosts, one for each host species from this study, are preserved in the UAM: O. collaris, UAM no. 58399 (AF 49330), male, 1 August 2001 (collected by H. Henttonen, J. Niemimaa, K. Gamblin, L. B. Barrelli) and $O$. hyperborea, UAM no. 80824 (AF 38535), 4 September 2000 (collected by S. O. MacDonald, N. E. Dokuchaev, K. E. Galbreath). Photosyntype of a sporulated oocyst in the USNPC as no. 87393.

Remarks: The morphology of sporulated oocysts of E. calentinei from $O$. hyperborea in Russia and $O$. collaris in Alaska is nearly identical to those described by Duszynski and Brunson (1973) for the same species collected from $O$. princeps in Colorado. The recovery of $E$. calentinei establishes new geographic records for this parasite in Russia and Alaska.

\section{Eimeria cryptobarretti Duszynski and Brunson, 1973}

Type host: O. princeps (Richardson, 1828), American pika. Other hosts (this study): O. collaris, $O$. hyperborea.

Type locality: North America: U.S.A.: Colorado, Larimer and Clear Creek counties.

Geographic distribution: North America: Colorado: Larimer and Clear Creek counties; Alaska: Wrangell-St. Elias National Park (this study), Yukon-Charley Rivers National Preserve, mountainside NW of Headwater Lake of Crescent Creek, $64^{\circ} 82^{\prime} \mathrm{N}, 143^{\circ} 75^{\prime} \mathrm{W}$ (this study); Asia: Russia: Siberia, Magadanskaya Oblast, mouth of Kegali River, $64^{\circ} 26^{\prime} \mathrm{N}, 161^{\circ} 47^{\prime} \mathrm{E}$ (this study).

Prevalence: $6 / 53(11 \%)$ O. collaris in Alaska (this study); 5/35 (14\%) O. hyperborea in Siberia (this study); 107/167 (64\%) O. princeps (type host) in Colorado.

Material deposited: Skin, skull, skeleton, and tissues of 2 symbiotype hosts, one for each host species from this study, are preserved in the UAM: O. collaris, UAM no. 58213 (AF 49535), 18 July 2001 (collected by $\mathrm{H}$. Henttonen, J. Niemimaa, K. Gamblin, L. B. Barrelli) and $O$. hyperborea, UAM no. 80603 (AF 38233), male, 19 August 2000 (collected by S. O. MacDonald, N. E. Dokuchaev, K. E. Galbreath). Photosyntype and photoparatype of sporulated oocysts are in the USNPC, nos. 87480 and 88170 , respectively.

Remarks: The morphology of E. cryptobarretti from $O$. hyperborea in Russia and $O$. collaris in Alaska is similar to the description by Duszynski and Brunson (1973) for the same species collected from $O$. 
TABLE I. Ten studies documenting the presence of coccidia (Eimeria, Isospora spp.) in pikas (Ochotona spp.) from 2 continents.

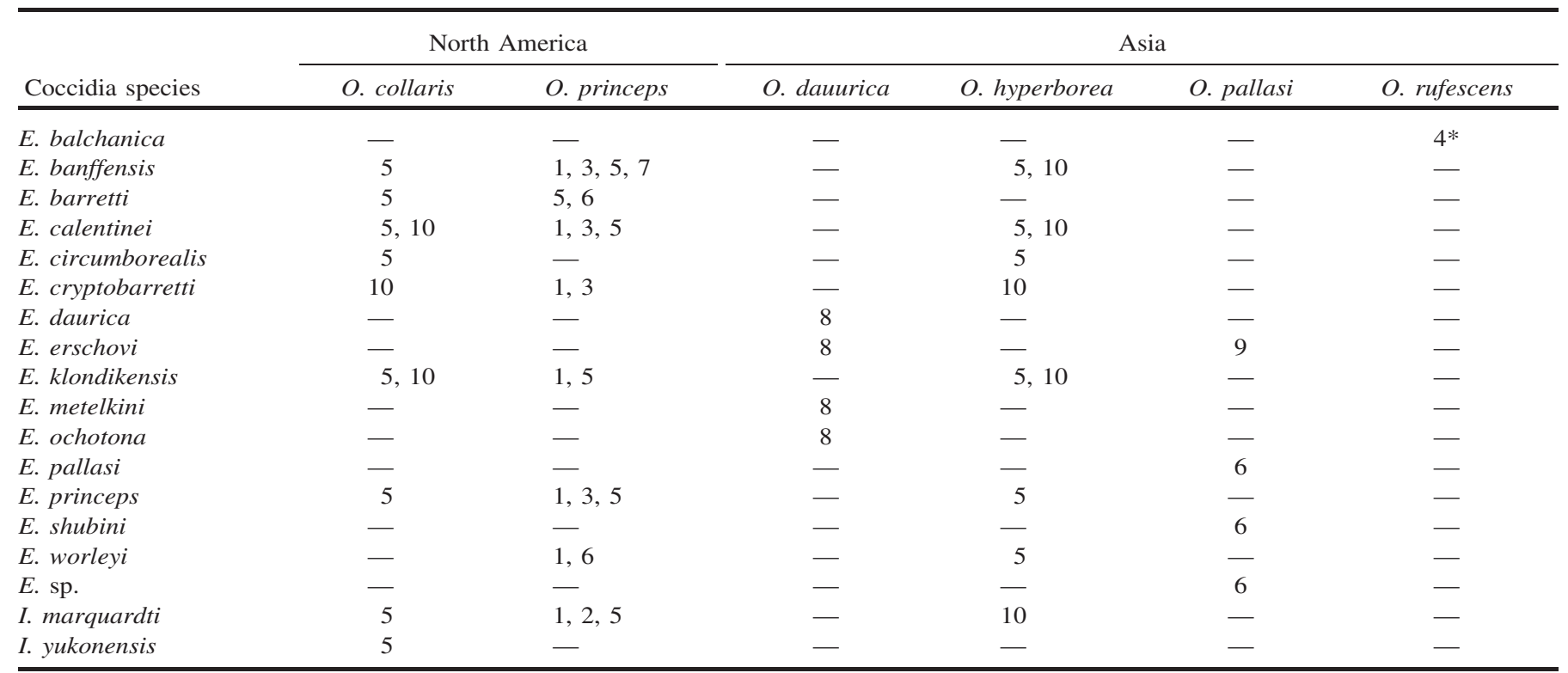

* 1. Duszynski, 1974; 2. Duszynski and Brunson, 1972; 3. Duszynski and Brunson, 1973; 4. Glebezdin, $1978 ; 5$. Hobbs and Samuel, $1974 ; 6$. Lepp et al., $1972 ; 7$. Lepp et al., 1973; 8. Machulsky, 1949; 9. Svanbaev, 1958; 10. Present study.

princeps in Colorado, U.S.A. The recovery of E. cryptobarretti establishes new host and geographic records for this parasite in Russia and Alaska, U.S.A. The authors of the original description hesitated to state if there was a micropyle on the oocyst, but we now believe that $E$. cryptobarretti does indeed have one.

\section{Eimeria klondikensis Hobbs and Samuel, 1974}

Type host: O. collaris (Nelson, 1893), collared pika.

Other hosts (this study): O. hyperborea.

Type locality: North America: Canada: Yukon Territory, Ogilvie Mountains, $64^{\circ} \mathrm{N}, 138^{\circ} \mathrm{W}$.

Geographic distribution: North America: Canada: Yukon Territory, Ogilvie Mountains, $64^{\circ} \mathrm{N}, 138^{\circ} \mathrm{W}$; Alberta, $51^{\circ} \mathrm{N}, 115^{\circ} \mathrm{W}$; U.S.A.: Colorado: Clear Creek County; Alaska: Wrangell-St. Elias National Park and Preserve, SE of Rock Lake, 21 July $2001,61^{\circ} 47^{\prime} \mathrm{N}, 141^{\circ} 12^{\prime} \mathrm{W}$ (this study); Yukon-Charley Rivers National Preserve (this study); Asia: Japan: Hokkaido, Daisetzusan National Park; Russia: Siberia, Chukotka, $3 \mathrm{~km}$ SSE of confluence of Volchya River and Liman Sea, $64^{\circ} 48^{\prime} \mathrm{N}$, $177^{\circ} 33^{\prime} \mathrm{E}$ (this study).

Prevalence: 2/53 (4\%) O. collaris in Alaska (this study); 3/92 (3\%) O. collaris (type host) in Yukon Territory; 1/35 (3\%) O. hyperborea in Siberia (this study); $2 / 14$ (14\%) O. hyperborea in Japan; $7 / 111(6 \%)$ O. princeps in Alberta; 62/224 (28\%) O. princeps in Colorado.

Material deposited: Skin, skull, skeleton, and tissues of 2 symbiotype hosts, one for each host species from this study, are preserved in the UAM: O. collaris, UAM no. 56067 (AF 54551), female, 21 July 2001 (collected by S. Kutz, A. Tsvetkova, A. A. Eddingaas, M. McCain) and O. hyperborea, UAM no. 84369 (IF 5253), male, 11 August 2002 (collected by N. E. Dokuchaev, A. A. Tsvetkova). We deposited a photoneotype of a sporulated oocyst in the USNPC as no. 99671, because no previous authors had archived a type specimen of this parasite.

Remarks: The morphology of E. klondikensis from O. collaris in Alaska and $O$. hyperborea in Russia is similar to the description provided by Hobbs and Samuel (1974) for the same species collected and described from the same hosts in Canada and Japan, respectively. The recovery of E. klondikensis establishes new geographic records for this parasite in Russia and Alaska, U.S.A. Both a line drawing and a photomicrograph of the sporulated oocyst of this species appeared in the original description.

\section{Isospora marquardti Duszynski and Brunson, 1972}

Type host: O. princeps (Richardson, 1828), American pika. Other hosts (this study): O. hyperborea.

Type locality: North America: U.S.A.: Colorado, Ft. Collins, Clear Creek, and Larimer counties.

Geographic distribution: North America: U.S.A.: Colorado, Ft. Collins, Clear Creek, and Larimer counties; Canada: Yukon Territory, Ogilvie Mountains, $64^{\circ} \mathrm{N}, 138^{\circ} \mathrm{W}$; Alberta, $51^{\circ} \mathrm{N}, 115^{\circ} \mathrm{W}$; Asia: Russia: Siberia, Chukotka, Ulhum River, $15 \mathrm{~km} \mathrm{~W}$ of Chaplino Village, $64^{\circ} 25^{\prime} \mathrm{N}$, $172^{\circ} 32^{\prime} \mathrm{E}$ (this study).

Prevalence: $1 / 92$ (1\%) O. collaris in the Yukon Territory (this study); $1 / 35(3 \%)$ O. hyperborea in Siberia (this study); $1 / 111(<1 \%)$ O. princeps in Alberta; 25/167 (15\%) O. princeps (type host) in Colorado.

Material deposited: Skull, skeleton, and tissues of a symbiotype host from this study are preserved in the UAM as UAM no. 83836 (IF 7569), female, 28 July 2002 (collected by V. F. Fedorov, K. E. Galbreath). Photosyntype of a sporulated oocyst is in the USNPC as no. 87408.

Remarks: The morphology of sporulated oocysts of I. marquardti from $O$. hyperborea in Russia differ slightly from those of Duszynski and Brunson (1972) collected and described from O. princeps in Colorado; the latter had oocysts and sporocysts that were larger in both length and width $(31 \times 30$ and $19 \times 12$ vs. $28 \times 27$ and $17 \times 11)$ than those of our Russian specimens. Still, both oocysts and sporocysts reported here were larger than those measured by Hobbs and Samuel (1974) from $O$. collaris $(23 \times 22$ and $15 \times 9)$. Oocysts of some species are known to exhibit phenotypic plasticity (see Duszynski et al., 1992) and, given the similarity of qualitative data, we believe these oocysts are I. marquardti. The recovery of I. marquardti establishes a new host and geographic record for this parasite in Russia.

Machulsky (1949) published the first paper on coccidia in pikas. Since then, 9 additional papers, including this one, have described a total of 18 coccidia species in 6 Ochotona species: 2 from North American and 4 from Asia (Table I). The coccidia reported from 3 of those 6 hosts, $O$. collaris, $O$. princeps, and $O$. hyperborea, which are the best studied hosts (Table I), are remarkably similar. These hosts have all been studied on multiple occasions and 10 coccidia have been reported from them. Six of $10(60 \%)$ coccidia have been reported from all 3 hosts, whereas 3 others have been reported from at least 2 hosts. One species, Isospora yukonensis, has been reported from only a single individual of $O$. collaris (Hobbs and Samuel, 1974). The overlap of coc- 
cidia species among $O$. collaris, $O$. hyperborea, and $O$. princeps suggests the possibility that these coccidia may have evolved from a common ancestor, i.e., that shared coccidia faunas in 3 closely related pika species may reflect a single origin for the parasites in their common ancestor. On the other hand, this pattern may indicate that each coccidium had a common ancestor in the ancestor of the pikas. Thus, the parasite community may have a recent origin, but this doesn't say anything about relationships among these coccidia.

Except for Eimeria erschovi Machulsky, 1949, the 7 coccidia identified from the remaining Asian pikas, Ochotona dauurica (Eimeria daurica, Eimeria metelkini, Eimeria ochotona, in 1949), Ochotona pallasi (Eimeria pallasi, Eimeria shubini, Eimeria sp., in 1958), and Ochotona rufescens (Eimeria balchanica, in 1978), only have been identified once, each from 2-3 specimens of their single host species. Initially, the lack of overlap indicates that these coccidia may be more hostspecies specific, but nothing substantive is known about host specificity in pika coccidia. On the other hand, given the known distributions of the 3 host species, it is unlikely that these coccidia would ever come into contact with an Ochotona species different from the one in which it was first described; O. rufescens, the Afghan pika, is geographically separated from the other 2 species and, although the ranges of $O$. dauur$i c a$ and $O$. pallasi share some overlap, e.g., Mongolia, these species are separated both by altitude and biome (high mountain vs. desert, respectively). In addition, the obvious sampling bias doesn't allow meaningful comparisons. Finally, the question must be asked whether any of these 7 coccidia even still exist since 2 of the 3 host species are either endangered $(O$. pallasi) or threatened $(O$. rufescens $)$.

Our a posteriori hypothesis was that the similarity, or disparity, of coccidia infecting pikas would reflect the systematics and phylogenetics of the hosts. Work by Yu et al. (2000) on the phylogeny of 19 pika species included $O$. hyperborea, $O$. princeps, $O$. pallasi, and $O$. dauur$i c a$; sequences from $O$. collaris and $O$. rufescens were not incorporated. The data of $\mathrm{Yu}$ et al. (2000) indicated that there are 3 pika clades: a shrub-steppe group of 7 species (including $O$. dauurica), a northern group of 5 species (including $O$. hyperborea, O. pallasi, and $O$. princeps), and a mountain group of 7 species. Host-parasite data to date (Table I) support the notion that $O$. hyperborea and $O$. princeps may be infected by the same coccidia because they have descended from a recent common ancestor. If true, this would predict that the same or similar coccidia species will be found in other species from the northern group of Yu et al. (2000). In other words, the morphological similarity of the coccidia in this study might reflect close phylogenetic relationships that are a consequence of the close relationship between the hosts.

The data of Yu et al. (2000) posit that $O$. princeps is the most basal member of the northern group. Interestingly, $O$. pallasi is infected by an entirely different set of coccidia from other hosts in the northern clade. In fact, $O$. pallasi is infected by $E$. erschovi, a coccidium first identified from $O$. dauurica, a member of the shrub-steppe group of pikas. Despite an older association between $O$. dauurica and $O$. pallasi, it is possible that $E$. erschovi is a generalist parasite capable of a broad co-accommodation of hosts (Brooks, 1979). In other words, the association between $E$. erschovi and 2 deeply divergent pika lineages may suggest the generalist nature of this coccidium. These hosts are in relatively close contact as the range of $O$. pallasi overlaps that of $O$. dauurica, although they occupy different habitats (Chapman and Flux, 1990); unfortunately, it is not known if any burrowing or talus-dwelling pikas live in enough proximity to connect these pika lineages. Perhaps the other Eimeria spp. identified from O. pallasi (Eimeria pallasi, Eimeria shubini, and Eimeria sp.) are more derived (than those infecting $O$. princeps) and are results of recent speciation. This would keep the cospeciation hypothesis alive, but it is also possible that a host switch could have led to this association. Only phylogenetic (sequence) data for these coccidia will resolve the relationships among them.

It also is recognized that the dichotomy seen in Table I, where 3 hosts overlap in eimeriid fauna and the other 3 hosts have divergent fauna, could be the result of poor species descriptions. Both Hobbs and Samuel (1974) and Lepp et al. (1972) addressed this possibility. Hobbs and Samuel (1974) noted the extreme similarity between many of the "continental Asian" and the "North American" coccidia. In all cases, there were enough differences among those coccidia to prevent the synonymy of species. Before conclusions can be made regarding the validity of species descriptions, more Asian pikas must be surveyed. Finding evidence for cryptic species of coccidia in pikas also could be an im- portant issue for sorting out the origins of their host-parasite associations.

In conclusion, we emphasize 3 major points: (1) the similarity in coccidia fauna among $O$. princeps, $O$. collaris, and O. hyperborea; (2) the different and more diverse coccidia parasites in Asian hosts; and (3) the apparent widespread species of coccidia found in pikas representing 2 different host clades.

Thanks are due the multinational field teams in Alaska and Russia who made this work possible; in particular we thank L. B. Barrelli, N. E. Dokuchaev, A. A. Eddingaas, V. F. Fedorov, K. E. Galbreath, K. Gamblin, H. Henttonen, S. Kutz, S. O. MacDonald, M. McCain, J. Niemimaa, A. A. Tsvetkova, and other members of our field teams. We also thank K. Galbreath for his very helpful suggestions when reading an earlier version of this manuscript. This work was supported by NSFDEB grant 0196095, the Beringian Coevolution Project (to J.A.C.) and a subcontract on DEB 0196095 to UNM, coevolution of insectivores and their coccidia parasites in Beringia (to D.W.D.).

\section{LITERATURE CITED}

Brooks, D. R. 1979. Testing the context and extent of host-parasite coevolution. Systematic Zoology 28: 299-307.

. 1993. Critical comment: Extending the symbiotype concept to host voucher specimens. Journal of Parasitology 79: 631-633.

Chapman, J. A., And J. E. C. Flux. 1990. Rabbits, hares and pikas: Status survey and conservation action plan. International Union for Conservation of Nature and Natural Resources. Gland, Switzerland.

Cook, J. A., E. P. Hoberg, A. Koehler, S. O. MacDonald, H. Henttonen, L. Wickstrom, V. Haukisalmi, K. Galbreath, F. CherNYAVSKI, N. DOKUCHAEV, ET AL. 2005. Beringia: Intercontinental exchange and diversification of high latitude mammals and their parasites during the Pliocene and Quaternary. Mammal Science 30: S33-S44.

DUSZYNSKI, D. W. 1974. More information on the coccidian parasites (Protozoa: Eimeriidae) of the Colorado pika, Ochotona princeps, with a key to the species. Journal of Wildlife Diseases 10: 94-100.

- AND J. T. BRUnson. 1972. The structure of the oocyst and the excystation process of Isospora marquardti sp. n. from the Colorado pika, Ochotona princeps. Journal of Protozoology 19: 257259 .

1973. Structure of the oocysts and excystation processes of four Eimeria spp. (Protozoa: Eimeriidae) from the Colorado pika, Ochotona princeps. Journal of Parasitology 59: 28-34. -, M. J. PAtrick, L. Couch, And S. J. Upton. 1992. Eimerians in harvest mice, Reithrodontomys spp., from Mexico, California and New Mexico, and phenotypic plasticity in oocysts of Eimeria arizonensis. Journal of Protozoology 39: 644-648.

, AND P. G. WILBER. 1997. A guideline for the preparation of species descriptions in the Eimeriidae. Journal of Parasitology 83: 333-336.

Frey, J. K., T. L. Yates, D. W. Duszynski, W. L. Gannon, and S. L. GARDNER. 1992. Designation and curatorial management of type host specimens (symbiotypes) for new parasite species. Journal of Parasitology 78: 930-932.

GLEBEZDiN, V. S. 1978. About the coccidia fauna of wild mammals of south-western Turkmenistan. Izvestiya Akademii Nauk Turkmenskoi SSR 3: 71-78.

Hobbs, R. P., And W. M. SAmuel. 1974. Coccidia of pikas with specific reference to Ochotona collaris, O. princeps, and O. hyperborea yesoensis. Canadian Journal of Zoology 52: 1079-1085.

Hoberg, E. P., S. J. Kutz, K. E. Galbreath, and J. A. Cook. 2003. Arctic biodiversity: From discovery to faunal baselines-Revealing the history of a dynamic system. Journal of Parasitology 89: S84S95.

LePP, D. L., K. S. TodD, JR., AND W. M. SAMuel. 1972. Four new species of Eimeria (Protozoa: Eimeriidae) from the pika Ochotona princeps from Alberta and Ochotona pallasi from Kazakhstan. Journal of Protozoology 19: 192-195.

$\longrightarrow$, AND - 1973. Eimeria banffensis n. sp. (Protozoa: Eimeridae) from the pika Ochotona princeps from Alberta. Transactions of the American Microscopical Society 92: 305-307. Machulsky, S. N. 1949. About coccidia in rodents of southern areas 
of Buryat-Mongol, USSR. Trudy Buryat-Mongol'skoi Zooveterinarnogo Instituta 5: 40-56.

Svanbaev, S. K. 1958. Coccidia of rodents of Central Kazakhstan. Tru-

dy Instituta Zoologii, Akademii Nauk Kazahkskoi SSR 9: 183-186.

WiLson, D. E., AND D. M. REEDER. 2005. Mammal species of the world:
A taxonomic and geographic reference, 3rd ed. Johns Hopkins University Press, Baltimore, Maryland, 2142 p.

Yu, N., C. Zheng, Y. Zhang, AND W. Li. 2000. Molecular systematics of pikas (Genus Ochotona) inferred from mitochondrial DNA sequences. Molecular Phylogenetics and Evolution 16: 85-95.

\section{A Ribeiroia Spp. (Class: Trematoda)--Specific PCR-Based Diagnostic}

David M. Reinitz, Timothy P. Yoshino, and Rebecca A. Cole ${ }^{\star} \dagger$, University of Wisconsin-Madison, Department of Pathobiological Sciences, 2115 Observatory Drive, Madison, Wisconsin 53726; *United States Geological Survey National Wildlife Health Center, 6006 Schroeder Road, Madison, Wisconsin 53711; and †To whom correspondence should be addressed. e-mail: rebecca_cole@usgs.gov

ABSTRACT: Increased reporting of amphibian malformations in North America has been noted with concern in light of reports that amphibian numbers and species are declining worldwide. Ribeiroia ondatrae has been shown to cause a variety of types of malformations in amphibians. However, little is known about the prevalence of $R$. ondatrae in North America. To aid in conducting field studies of Ribeiroia spp., we have developed a polymerase chain reaction (PCR)-based diagnostic. Herein, we describe the development of an accurate, rapid, simple, and costeffective diagnostic for detection of Ribeiroia spp. infection in snails (Planorbella trivolvis). Candidate oligonucleotide primers for PCR were designed via DNA sequence analyses of multiple ribosomal internal transcribed spacer-2 regions from Ribeiroia spp. and Echinostoma spp. Comparison of consensus sequences determined from both genera identified areas of sequence potentially unique to Ribeiroia spp. The PCR reliably produced a diagnostic 290-base pair (bp) product in the presence of a wide concentration range of snail or frog DNA. Sensitivity was examined with DNA extracted from single $R$. ondatrae cercaria. The single-tube PCR could routinely detect less than 1 cercariae equivalent, because DNA isolated from a single cercaria could be diluted at least 1:50 and still yield a positive result via gel electrophoresis. An even more sensitive nested PCR also was developed that routinely detected $100 \mathrm{fg}$ of the 290-bp fragment. The assay did not detect furcocercous cercariae of certain Schistosomatidae, Echinostoma sp., or Sphaeridiotrema globulus nor adults of Clinostomum sp. or Cyathocotyle bushiensis. Field testing of 137 P. trivolvis identified 3 positives with no overt environmental cross-reactivity, and results concurred with microscopic examinations in all cases.

Concern over declining numbers and species of amphibians has come to the forefront over the past $20 \mathrm{yr}$ (Barinaga, 1990; Blaustein and Wake, 1990; Phillips, 1990; Pechmann et al., 1991; Wake, 1998). Suggested factors, singly or in synergism, that have been hypothesized as reasons for the decline of this class of animals include habitat destruction (Kolozsvary and Swihart, 1999; Houlahan and Findlay, 2003), UV irradiation (Blaustein et al., 1998, 2003), introduced species (Knapp and Mathews, 2000), climate change (Beebee, 1995; Corn, 2005), and various pathogens (Daszak et al., 2003). A current review of the factors is found in Beebee and Griffiths (2005). Amphibian malformations are of growing concern, because they have been observed with increased prevalence in North America (Ouellet, 2000). Although malformations have the potential to deleteriously affect populations or species at particular sites, they have not been empirically linked to global or regional declines. Recent reports (Johnson et al., 1999, 2002; Lannoo et al., 2003; Schoff et al., 2003; Schotthoefer et al., 2003) have implicated the trematode Ribeiroia ondatrae as a causative agent of some types of malformations. Little is known about the distribution of this parasite in its hosts within North America. Wilson et al. (2005) identified 3 species of Ribeiroia: $R$. ondatrae within the Americas; $R$. marini in the Carribbean, and Cercaria lileta in Africa. Ribeiroia ondatrae has a 3-host life cycle with 2 aquatic intermediate hosts and a predator definitive host, usually a bird or mammal. Planorbella spp. serves as first intermediate host, with fish and various amphibians as second intermediate hosts. Exogenous factors, which include pesticides (Kiesecker, 2002), and eutrophication, which leads to a dominance of Planorbella spp. (Johnson and Chase, 2004), have been shown to increase malformation rates. Currently, Ribeiroia spp. infections in the first intermediate host are diagnosed by dissection of live or freshly dead snail hosts for various larval stages, which requires training and substantial time to locate infected tissues to identify the parasite correctly. Identifying larvae early in development after miracidial penetration but before the development of the cercariae is difficult, if not impossible, using morphological characters. To increase the speed and accuracy in the examination of large numbers of snails for the presence of Ribeiroia spp., to reduce labor costs, and to simplify training required, we have developed a genusspecific polymerase chain reaction (PCR)-based diagnostic that targets the second internal transcribed spacer (ITS-2) region of the ribosomal RNA gene cluster (Morgan and Blair, 1998; Kostadinova et al., 2003; Wilson et al., 2005). By using various combinations of 4 oligonucleo-

TABLE I. Oligonucleotides and PCR profiles used to detect Ribeiroia sp.

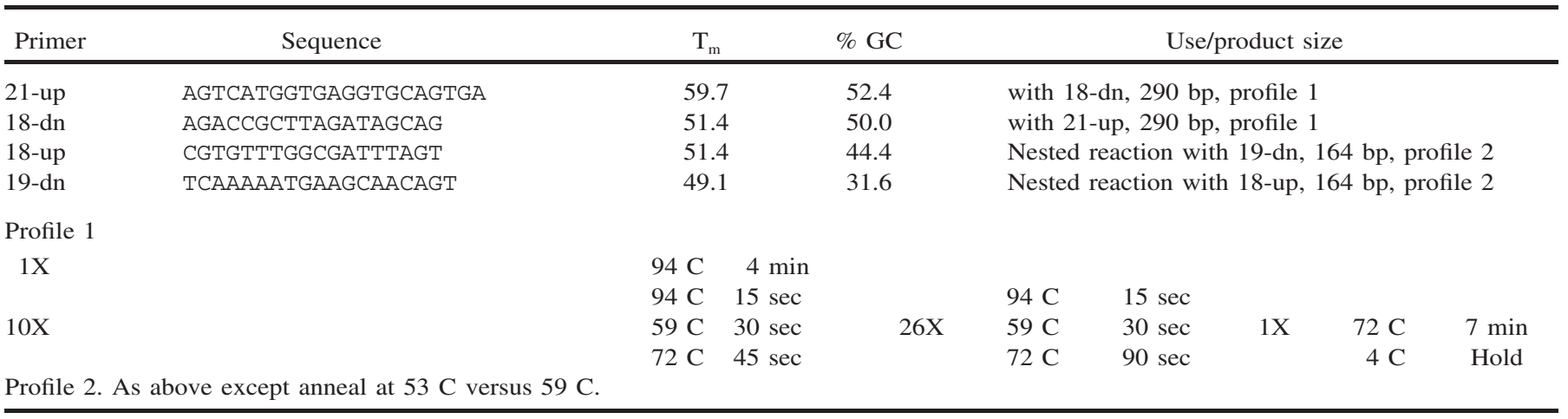

